\title{
Surface Graphite Formation of the Brown Colored Type I Diamonds During High Pressure Annealing
}

\author{
Jeongho Song and Ohsung Song ${ }^{\dagger}$ \\ Department of Materials Science and Engineering, University of Seoul, Seoul 130-743, Korea \\ (Received August 7, 2012; Revised September 11, 2012; Accepted September 11, 2012)

\section{갈색 Type I 다이아몬드의 고압 열처리에 따른 표면 흑연화 생성 연구} \\ 송정호· 송오성 ${ }^{\dagger}$ \\ 서울시립대학교 신소재공학과 \\ (2012년 8월 7일 접수 ; 2012년 9월 11일 수정 ; 2012년 9월 11일 채택)
}

\begin{abstract}
We investigated color and graphite layer formation on the surface of Type I tinted brown diamonds exposed for 5 minutes under a high-pressure high-temperature (HPHT) condition in a stable graphite regime. We executed the HPHT processes of Process I, varying the temperature from $1600^{\circ} \mathrm{C}$ to $2300^{\circ} \mathrm{C}$ under $5.2 \mathrm{GPa}$ pressure for 5 minutes, and Process II, varying the pressure from 4.2 to 5.7 $\mathrm{GPa}$ at $2150^{\circ} \mathrm{C}$ for 5 minutes. Optical microscopy and micro-Raman spectroscopy were used to check the microstructure and surface layer phase evolution. For Process I, we observed a color change to vivid yellow and greenish yellow and the growth of a graphite layer as the temperature increased. For Process II, the graphite layer thickness increased as the pressure decreased. We also confirmed by $531 \mathrm{~nm}$ micro-Raman spectroscopy that all diamonds showed a $1440 \mathrm{~cm}^{-1}$ characteristic peak, which remained even after HPHT annealing. The results implied that HPHT-treated colored diamonds can be distinguished from natural stones by checking for the existence of the $1440 \mathrm{~cm}^{-1}$ peak with $531 \mathrm{~nm}$ micro-Raman spectroscopy.
\end{abstract}

Key words : Graphite layer, HPHT treated, Type I diamond, Tinted brown colored diamond, Raman spectroscopy

\section{1. 서 론}

보석으로써 천연다이아몬드의 가치는 중량(carat weight) 이 클수록, 내부결함이 적어 클래리티가 우수할수록 전반 사 정도가 우수하도록 커팅이 잘 될수록, 무색투명한 컬 러를 지닐수록 우수하게 평가된다.

특히 컬러는 대부분의 다이아몬드에 $3000 \mathrm{ppm}$ 이상의 질소가 주로 혼합되어 갈색이 나는 다이아몬드가 상대적 으로 많아서 심미적으로 아름다운 밝은 노란색 또는 무 색투명한 컬러로 개선시키려는 노력이 계속되어왔다. ${ }^{1)}$

이미 1960년대부터 다이아몬드상이 안정한 고온고압 상 태에서 온도를 높여서 갈색색상의 주요원인인 질소의 결 합상태를 제어하여 색변화 시키는 기술이 개발되었다. ${ }^{2}$

1975년 Evans, Rainey 등ㄱ은 성공적으로 무색(colorless) Type I a다이아몬드를 HPHT 공정을 통해 옐로우(vivid yellow) 다이아몬드로 색향상 가능함을 보고하였다.

${ }^{\dagger}$ Corresponding author : Ohsung Song

E-mail : songos@uos.ac.kr

Tel : +82-2-2210-2978 Fax : +82-2-2215-5863
1977년 Chrenko 등 ${ }^{4)}$ 은 HPHT 처리한 다이아몬드의 물 성 분석을 하여 다이아몬드 내부 질소의 결함 변화에 따 라 다이아몬드 색향상이 이루어진다는 것을 규명하였다. 최근에는 Vagarali 등 ${ }^{5)}$ 에 의해 Type I과 Type II 다이아몬 드의 색상개선이 성공적으로 가능함이 보고되고 있다.

이러한 다이아몬드의 열처리는 Fig. 1과 같이 다이아몬 드와 흑연의 압력-온도 상태도에서 $\mathrm{A}, \mathrm{B}, \mathrm{C}$ 로 표시한 영 역을 포함하는 다이아몬드 안정화 구간에서 실시된다. 만 약 다이아몬드가 $\mathrm{A}, \mathrm{B}, \mathrm{C}$ 구간 하단부의 다이아몬드-흑 연 구역선을 기준으로 아랫부분인 흑연 안정화 구간에서 처리되면 처리하고자 하는 다이아몬드의 일부가 흑연화 되어 이를 제거하기 위해 중량손실이 커져서 가치가 급 격히 하락하므로 가능하면 다이아몬드 안정화 구간에서 열처리가 진행되어야 한다.

일반적인 다이아몬드 안정 영역에서의 처리를 위해서 는, 비교적 저온 저압인 $\mathrm{A}$ 영역에서는 질소의 본딩상태를 재배열할 만큼의 충분한 열에너지가 제공되지 않으므로 매우 긴 공정시간이 필요하여 색향상 처리에 적절하지 않 고, 초고온 초고압인 $\mathrm{C}$ 영역에서는 초고압을 초고온상태 에서 유지하여야하므로 기술적으로 처리 공정 중 앤빌의 


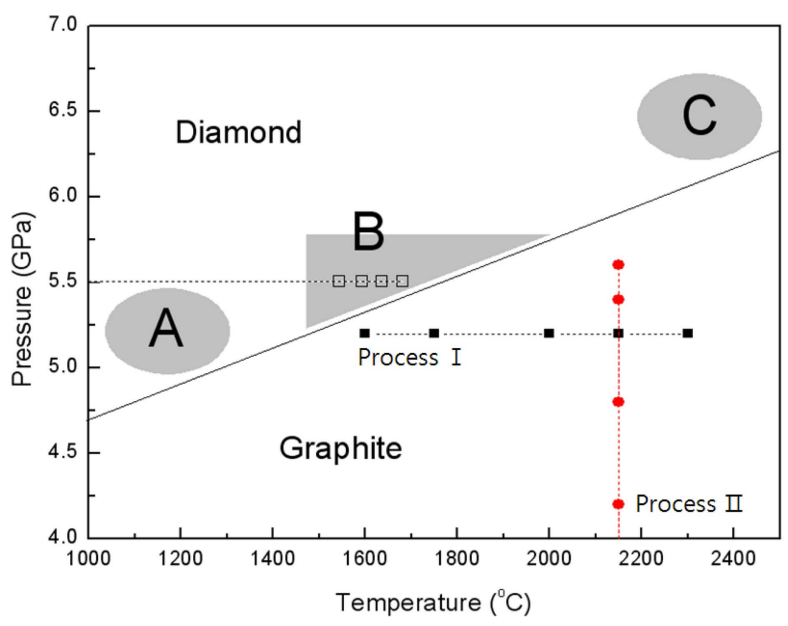

Fig. 1. P-T phase diagram of the diamond and graphite.

(a)

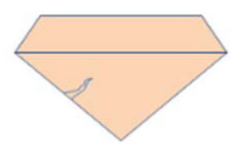

(b)
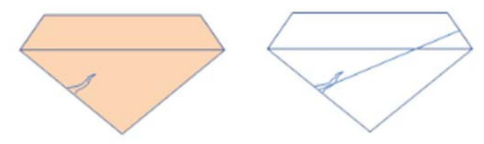

(c)
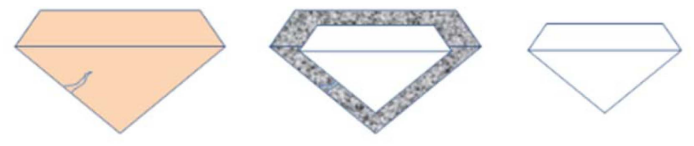

Fig. 2. Formation of the graphite layers on diamonds with localized cracks.

파괴 또는 다이아몬드 자체의 파괴가 일어나 수율이 떨어 질 수 있다. 따라서 $\mathrm{B}$ 영역인 $5.5 \sim 6.5 \mathrm{GPa}, 1500 \sim 1800^{\circ} \mathrm{C}$ 정 도의 압력온도 구간이 비교적 현실적으로 다이아몬드의 색 향상을 위한 처리공정 조건으로 바람직하다. 이봉)은 $\mathrm{B}$ 영역인 $5.6 \mathrm{GPa}$ 에서 $1750^{\circ} \mathrm{C}$ 의 조건으로 성공적으로 Type I 과 Type II 갈색 다이아몬드를 흑연층 생성에 의한 재연 마 공정 없이 색향상 시킬 수 있음을 보고한 바 있다. 그 러나 실제적으로는 B영역에서도 국부적인 압력변화가 있 는 경우나 압력과 온도 보정이 잘못되어 $\mathrm{B}$ 영역 아래 조 건에서 공정이 진행된다면 30 초 정도의 빠른 고온고압처 리에도 다이아몬드 표면 또는 내부에 흑연점이 생기거나 페더가 성장하여 파괴가 일어나는 문제가 있다. 특히 이 러한 문제가 발생할 경우 색처리 공정에서 다이아몬드의 가치를 저하시키는 치명적인 요소인 표면부에 생성되는 흑연화 현상을 정량적으로 예측한 연구는 미흡한 상황이다.

고온고압을 이용한 다이아몬드의 색향상은 만약 다이 아몬드 내외부에 크랙이 존재할 경우 고온고압 처리 시 에 압력불균형이 생겨 Fig. 2의 (a)열에 나타낸 바와 같이 왼쪽의 처리 전의 다이아몬드 크랙부위가 오른쪽의 처리
후에는 흑연상으로 변화되거나, (b)열에 나타낸 바와 같 이 궁극적으로 처리과정 중에 파괴가 일어나 결국 오른 쪽의 그림과 같이 작은 2 개의 다이아몬드로 재가공하여 사용하여야하므로 다이아몬드로서의 가치가 급락하는 문 제가 있다. 이러한 문제를 극복하기 위해서 (c)열에 나타 낸 바와 같이 이미 많은 크랙이 있어 고온고압 처리에 적 합하지 않은 다이아몬드 시편이라면 파괴가 일어나지 않 는 저압조건에서 흑연상의 생성을 감수하고 일단 색향상 을 수행하고, 이후 전체적인 재연마를 통하여 보석을 얻 어서 무게 감소에 따른 가치하락보다 색향상에 의한 가 치상승이 더 높게 하는 공정이 적용될 수 있다. 다만 이 를 위해서는 정량적으로 다이아몬드의 흑연화 생성량을 예측하고 평가할 수 있어야 중량감소에 따른 가치하락을 고려한 색향상 열처리 진행여부를 판단할 수 있으므로 이 러한 표면 흑연층 생성에 대한 정량적인 연구가 필요하다. 따라서 본 연구에서는 Fig. 1에 검은 사각형(ם)과 원(O 으로 표시한 다이아몬드의 비안정 온도, 압력 구간에서 천연다이아몬드의 고온고압처리를 수행하고 이때의 다이 아몬드의 표면 흑연층의 생성 정도를 정량적으로 확인하 고자 하였다.

\section{2. 실험방법}

다이아몬드는 모두 Type I의 갈색(tinted brown)으로 $0.30 \sim 0.36 \mathrm{ct}$ 의 58 면의 패싯면(facet)을 가진 라운드브릴리 언트(round brilliant) 컷이 된 9개의 시료를 준비하였다.

다이아몬드의 색향상을 위한 고온고압 처리는 $\Phi 420 \mathrm{~mm}$ 크기의 6개 실린더를 가진 육면정프레스(Guilin $420 \mathrm{~mm}$ ) 를 활용하여 진행하였다. 육면정프레스는 $38 \mathrm{~mm}$ 의 정육 면체 셀(cell)에 $10 \mathrm{GPa}, 2500^{\circ} \mathrm{C}$ 까지 압력과 온도를 가할 수 있으며, 육방정형의 프레스 본체와 유압펌프 시스템, 컨트롤러로 구성되었다.

Fig. 3에는 육면정프레스의 중앙부에 위치하는 다이아 몬드 시료를 포함하는 셀의 구조를 나타내었다. 셀의 외 부는 캐스킷 역할을 하는 엽납석(pyrophillite)를 기본으로 하고, 상하 양쪽의 끝에는 전기를 통하게 하는 전극체로 탄소강과 저항열로 고온을 발생시키는 흑연튜브와의 내 열성을 위해 $\mathrm{Mo}$ 디스크를 위치시켰다. 또한 내부의 중앙 에는 색향상을 목적으로 하는 다이아몬드 시편을 위치시 키고 주변부에는 압력을 전달시키는 목적으로 $\mathrm{MgO}$ 소결 체를 채웠다. 이러한 셀은 이후 각 6 면을 육면정프레스의 6 개 초경 앤빌로부터 압력을 받아 셀 내부에 목적하는 고 온고압 상태를 유지하도록 하였다.

이때 셀 내부의 정확한 온도 조절을 위해서 온도 칼리브 레이션(calibration)을 Pt-6\%Rh/Pt-30\%Rh 열전쌍(thermocouple) 을 Fig. 3의 다이아몬드라고 표시한 셀 중심부에 위치시 키고 외부에서 인가하는 전류량에 따른 온도변화를 측정 


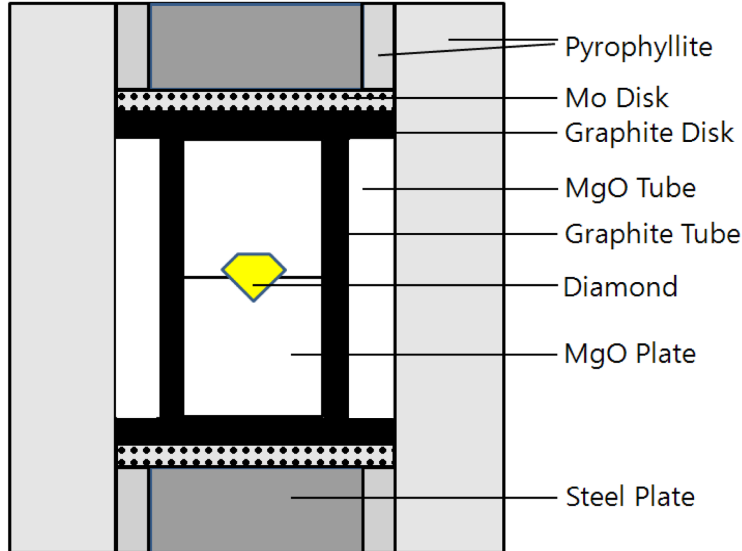

Fig. 3. A schematic illustration of the HPHT cell with a graphite tube.

하여 확인하였다. 압력의 보정을 위해서는 $5.5 \mathrm{GPa}$ 에서 전 기저항의 급격한 변화를 보이는 물성을 가진 $\mathrm{Ba}$ 순금속 을 이용하였다. 셀 중심부에 $\mathrm{Ba}$ 순금속을 위치시키고 전 기저항의 변화를 확인하기위해 셀 양측면부에 구멍을 뚫 어 저항측정기에 연결하였다. 이후 온도는 상온으로 유지 하며 인가압력을 서서히 올려주면서 저항값을 확인하여 순간적으로 변화를 보이는 구간의 압력을 확인 한 후 $5.5 \mathrm{GPa}$ 를 기준으로 선형적으로 인가하는 압력을 보정하 여 실제 셀 내부의 압력을 결정하였다.

고온고압 공정 조건은 시간을 5 분, 압력을 $5.2 \mathrm{GPa}$ 로 고 정하고 온도는 $1600,1750,2000,2150,2300^{\circ} \mathrm{C}$ 로 변화시 키는 공정 I을 Fig. 1의 Process I으로 표시한 바와 같이 수행하였다. 또한 압력변화에 따른 흑연층을 확인하기 위 해 공정시간은 역시 5 분으로 고정하고 온도는 $2150^{\circ} \mathrm{C}$ 로 고정시키고 압력을 $4.2,4.7,5.2,5.2,5.5,5.7 \mathrm{GPa}$ 범위로 변화시키는 공정 II를 Fig. 1의 Process II 영역에 표시한 바와 같이 수행하였다.

고온고압이 완료된 시편은 보석용현미경(GIA)과 여기 에 연결된 디지털카메라를 이용하여 60 배까지 촬영하고 특히 고온고압 전후의 표면흑연부를 리폴리싱하여 제거 한 후 시료의 표면부와 내부 미세구조의 변화를 관찰하였다.

흑연층의 두께는 연마 후의 무게변화를 측정하여 간접 적으로 확인하였다. 흑연층의 두께를 정량적으로 수직단 면 확대분석을 통하여 확인하지 않은 이유는 다이아몬드 시료의 비용이 비싸서 수직단면 확인을 위한 파괴검사보 다는 간접적으로 무게변화를 확인하여 무게감소에 따른 흑연생성을 확인한 것이다.

또한 UniThink 사의 라만분광기 (Raman spectroscopy, UniRaman)를 이용하여 고온고압 처리 전후와 리폴리싱 후의 다이아몬드 표면부를 관찰하였다. 이때 DPSS laser 의 광원은 $531 \mathrm{~nm}$ 유지하며 Back-illuminated $\mathrm{CCD}$ 를 검 출기로 이용하여 노출 시간을 $5 \mathrm{sec}$ 로 하여 광범위 영역을
측정하였다. 특히 다이아몬드, DLC (diamond-like carbon), 흑연의 경우 각각 $1332,1440,1600 \mathrm{~cm}^{-1}$ 에서 각각 라만 특성 피크가 나오는 것으로 알려져 있으므로 이로써 다 이아몬드와 기타 카본계 준안정상의 형성을 정성적으로 분석하였다. ${ }^{7,8)}$

\section{3. 결과 및 고찰}

Fig. 4에는 고온고압 공정 I (5 min at $5.2 \mathrm{GPa})$ 에 의해 (a) $1600^{\circ} \mathrm{C}$, (b) $1750^{\circ} \mathrm{C}$, (c) $2000^{\circ} \mathrm{C}$, (d) $2150^{\circ} \mathrm{C}$, (e) $2300^{\circ} \mathrm{C}$ 까 지 온도를 변화시켜 고온고압 처리한 전후의 다이아몬드 들의 이미지를 나타내었다. 왼쪽 열은 모두 처리 전의 다이 아몬드들의 이미지를 나타내었다. 약 $4.2 \mathrm{~mm}$ 직경의 Type I 갈색(tinted brown)의 비슷한 칼라를 가진 유색 다이아몬 드임을 알 수 있다. 가운데 열은 왼쪽열의 다이아몬드들 을 고온고압처리 시킨 직후의 표면 흑연화 된 모습을 촬 영한 결과물들이고 맨 오른쪽 열은 처리 후 생긴 표면 흑 연층을 기계적 연마를 이용하여 제거한 후의 광학현미경 이미지들이다.

Fig. 4 (a), (b)의 비교적 저온에서 처리된 경우는, 아직 흑연층이 발달하지 못하고 쉽게 철솔로도 제거되어 반투 명한 다이아몬드의 이미지는 볼 수 있으나, 이미 표면이 거칠어져 보석으로서의 표면광택을 잃어버렸음을 나타낸 다. 따라서 이러한 흑연층의 성장은 일반적인 확산현상과 같이 압력 전달매체인 $\mathrm{MgO}$ 소결체와 맞닿은 표면부 부 터 흑연의 핵생성이 생기고 이후 이 핵이 표면 내부로 확 산 메커니즘으로 성장할 것이 예상된다. 이 때 최종적으 로 주어진 온도와 시간에 따른 흑연층의 두께 (d)는 $d=$ $K \sqrt{\exp \left(-\frac{Q}{k T}\right) t}$ 의 일반적인 확산식(여기서 $\mathrm{d}$ 는 흑연층의두께, $\mathrm{K}$ 는 비례상수, $\mathrm{Q}$ 는 활성화에너지, $\mathrm{T}$ 는 처리온도 절대온 도, $\mathrm{t}$ 는 처리시간)을 따라 온도가 증가하면 위로 볼록한 루트함수 형태로 증가할 것이 예상된다. ${ }^{9)}$ 그리고 일단 생 성된 흑연층은 철솔로 제거하여도 제거가 진행되지 않았 고, 흑연만 선택적으로 용해시키는 $80^{\circ} \mathrm{C}-90 \% \mathrm{H}_{2} \mathrm{SO}_{4}$ 에서 화학적으로 크리닝 하여도 제거되지 않는 특징이 있었다. 따라서 부득이하게 보석으로서의 광택을 회복하기 위해 서는 다이아몬드 미세분말을 연마재로 채용하여 회전판 으로 각 면을 재연마시켜서 Fig. 4의 오른쪽 이미지들을 얻었다. 재연마된 이미지를 보면 (c)의 $2000^{\circ} \mathrm{C}$ 까지는 밝 은 노란색 (vivid yellow)으로 변화함을 알 수 있고 (d)의 $2150^{\circ} \mathrm{C}$ 에서는 진한 밝은 노란색으로 변화되었다가, (e)의 $2300^{\circ} \mathrm{C}$ 가 되면 그린색이 도는 노란색 (greenish yellow)으 로 색변화가 일어났다. 이러한 색변화의 패턴은 다이아몬 드 안정영역에서 비슷한 갈색 Type I 다이아몬드 실험을 실시한 이봉 등 ${ }^{10}$ 의 보고와 잘 일치하였다.

그러나 (e)에서는 색변화 외에 사진의 9시 방향과 같이 
(a)

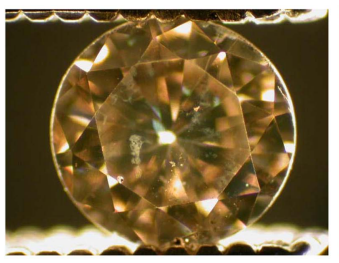

(b)

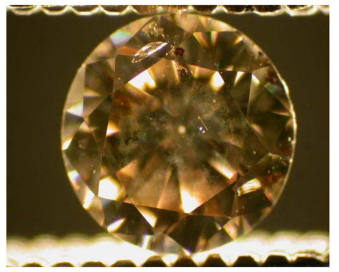

(c)

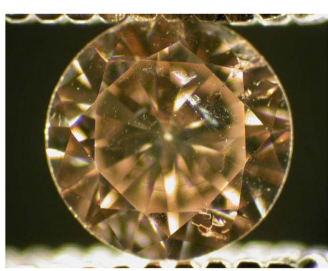

(d)

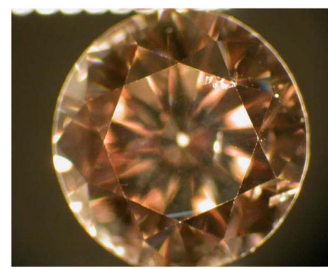

(e)

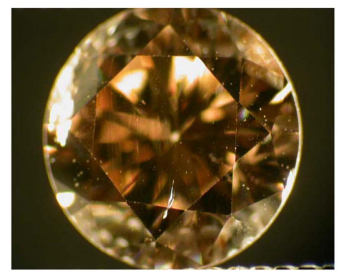

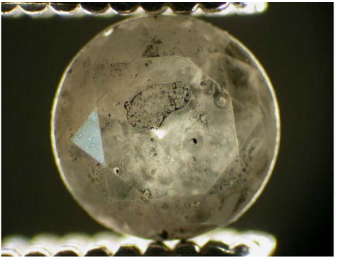
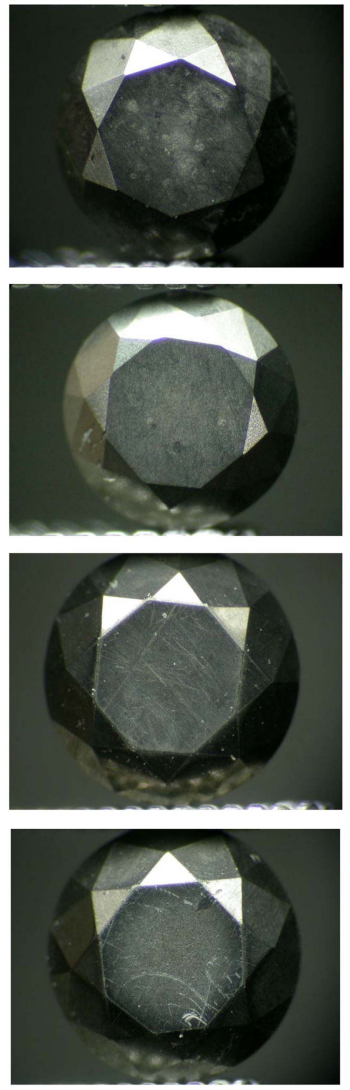
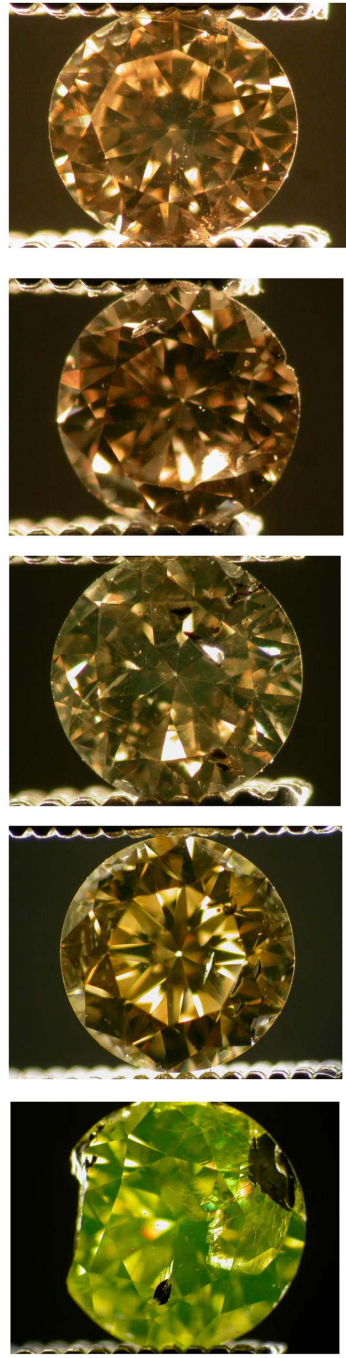

Fig. 4. Optical micro-images of the brown Type I diamonds : Lefts are before treated, centers are after HPHT treated, and rights are treated and repolished. HPHT treated at (a) $1600^{\circ} \mathrm{C},(\mathrm{b}) 1750^{\circ} \mathrm{C},(\mathrm{c}) 2000^{\circ} \mathrm{C},(\mathrm{d}) 2150^{\circ} \mathrm{C}$, and (e) $2300^{\circ} \mathrm{C}$.

재연마 과정 중에서 처리 전 시편의 크랙이 발달하여 파 괴되는 문제점과 내부 깨진 면에 국부적으로 흑연의 층 이 생성되어(2시 방향, 9시 방향) 표면 재연마만으로는 이 러한 내부 흑연점을 제거하지 못하고 오히려 보석으로서 의 가치가 저하되는 문제가 있었다.

따라서 다이아몬드의 비안정영역에서의 고온 고압처리 는 비교적 저온에서 실시하는 것이 흑연층 성장을 억제 하여 단결정 다이아몬드의 중량손실을 방지하는데 유리 하다고 예상할 수 있었다. 또한 이러한 표면부의 흑연층 의 생성현상은 가장 경도가 큰 다이아몬드를 가공하는 공 정으로도 응용이 가능한데, 만약 보석용으로 아직 연마하 지 않은 특정 형태의 갈색 다이아몬드 원석에 대하여 색 향상을 실시함과 동시에 표면부의 거친면을 제거해야 한 다면 단단한 다이아몬드보다는 상대적으로 부드러운 표 면 흑연층을 성장시키고 이를 상대적으로 쉽게 보석용으 로 커팅하는 응용 공정으로 제거하는 것이 가능하다고 예
상되었다.

다이아몬드의 재연마된 이미지를 보면 모든 다이아몬 드 내부에는 흑연층이 생성되지 않고 표면부에만 한정하 여 생성되었음을 알 수 있다. 다이아몬드의 고온고압처리 에서 생성된 흑연층은 외부의 흑연발열체로부터 오염된 것이 아니라 다이아몬드 자체의 표면부로부터 흑연의 불 균일 핵생성이 진행되고 이후 흑연상이 계속 성장하였음 을 알 수 있다. Fig. 5(a)에 나타낸 바와 같이 흑연의 핵 생성은 형상효과에 의해 표면부에 빠른 캡형의 핵생성이 진행된다고 가정하면 열역학적으로 내부에 구형태의 균 일핵생성보다 작은 임계자유에너지를 넘어 쉽게 형성되 고, 이 핵이 (b)에 나타낸 바와 같이 판상성장을 하여 표 면부에 한정된 흑연층이 생성되었다고 판단된다. 따라서 표면부의 흑연층을 재연마함으로써 중량손실은 발생하였 으나 다시 색향상에 의해 전체적으로는 보석의 가치가 향 상되었다고 판단되었다. 


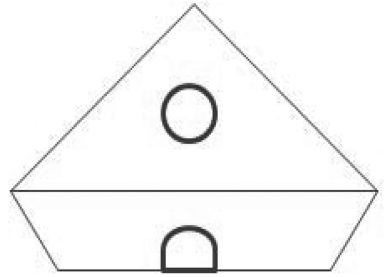

(a)

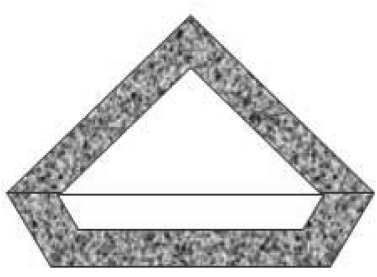

(b)
Fig. 5. Illustrations of (a) the nuclei on the surface and inside, and (b) the growth of graphite layer on the surface of a diamond.

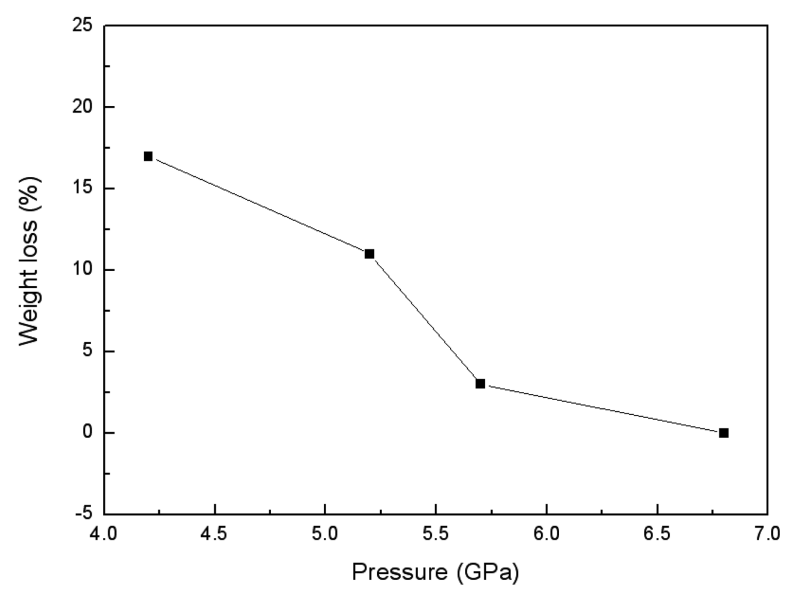

Fig. 6. Weight loss of diamonds with HPHT annealing temperatures.

한편 Fig. 6 에는 공정 II ( $5 \mathrm{~min}$ at $\left.2150^{\circ} \mathrm{C}, 4.2 \sim 5.7 \mathrm{GPa}\right)$ 에 의한 공정을 수행하고 난 후에 재연마 이후 각 시표 의 중량손실을 나타내었다. 재연마 정도는 물론 정확하지 는 않지만, 숙련된 연마사에 의해 진행되어, 정성적으로 는 압력이 감소하면 점점 흑연층이 두꺼워져서 재연마 후 중량손실이 더 커지는 경향을 확인하였다. 또한 모든 시 편은 재연마 후에 성공적으로 브라운칼라가 비비드옐로 우 색으로 변화하였음을 확인하였다. $4.2 \mathrm{GPa}$ 에서 고온고 압처리를 한 경우 최대 $17 \%$ 의 중량감소가 생겼고, 이후 압력이 높아짐에 따라 $5.7 \mathrm{GPa}$ 에서 $3 \%$ 정도로 크게 감소 하였다. 이는 같은 온도에서 다이아몬드가 안정한 부분으 로 압력이 높아짐에 따라 흑연층의 두께도 감소되는 것 을 확인 할 수 있었으며, 이후 $6.7 \mathrm{GPa}$ 에서 처리하면 다 이아몬드 안정영역에서 처리되므로 다이아몬드에 흑연층 이 생성되지 않음을 확인하였다.

Fig. 7에는 HPHT 처리를 $2000^{\circ} \mathrm{C}$ 에서 실시한 시편의 처 리에 따른 마이크로 라만 스펙트럼 결과를 나타내었다. 하단부의 처리전의 갈색 다이아몬드는 다이아몬드의 특 성피크인 $1332 \mathrm{~cm}^{-1}$ 외에 특이하게 $1440 \mathrm{~cm}^{-1}$ 의 이차피크 가 보이고 있다. 이러한 이차피크는 다른 천연 칼라리스 다이아몬드에서는 알려지지 않은 피크로서 Type I 갈색 다이아몬드의 질소결합에 의한 특성피크로 판단된다. 본 연구에서 진행한 모든 다이아몬드는 처리 전에 이러한 2

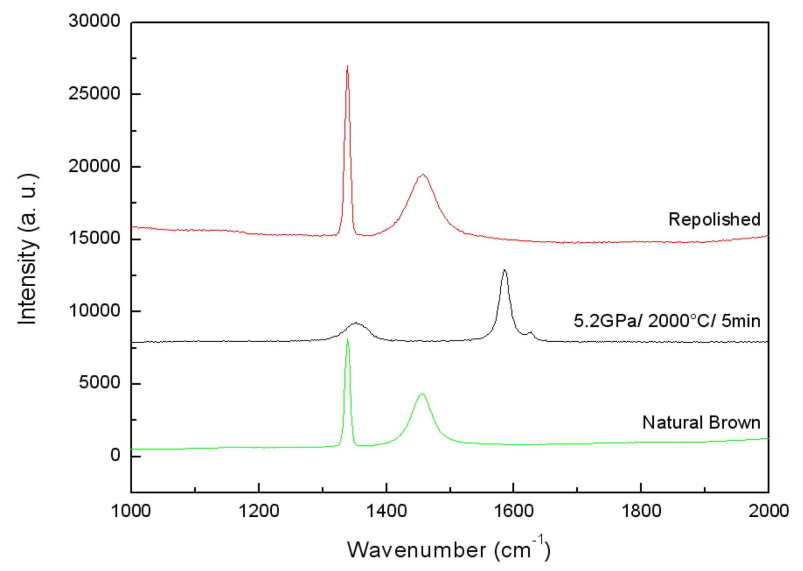

Fig. 7. Micro-Raman spectra of diamonds before the treatment, diamonds treated under HPHT, and repolished diamonds.

개의 피크를 보이는 특징이 있었다. 반면 가운데의 HPHT 처리 직후의 스펙트럼에서는 두꺼운 흑연층에 의해 흑연 의 특성피크인 $1600 \mathrm{~cm}^{-1}$ 가 크게 나타나고 반면에 다이아 몬드의 특성피크는 매우 감소하여 브로드하게 나타남을 알 수 있다. 라만분광기의 레이저의 표면 침투 깊이(skin depth)를 고려하면 정상적으로 온도가 올라가면서 흑연의 특성피크는 증가하고 다이아몬드의 특성피크는 감소하는 온도에 따른 경향성을 확인할 수 있었다.

한편 상단부의 흑연층을 제거한 리플리싱 후의 스펙트럼 을 보면 하단부의 처리전 시편과 마찬가지로 $1332 \mathrm{~cm}^{-1}$ 과 $1440 \mathrm{~cm}^{-1}$ 의 두 가지 특성피크를 보이고 있다. 특히 $1440 \mathrm{~cm}^{-1}$ 피크가 고온고압 처리후에도 변하지 않고 유지 되고 있는 특징은 다른 온도에서 처리한 후 리폴리싱 한 다 이아몬드들에서도 모두 발견되어 $1440 \mathrm{~cm}^{-1}$ 피크는 Type I 갈색다이아몬드를 고온고압 처리하여 색향상한 이후에도 계속 남게되는 특성피크라고 판단되었다. 따라서 기존의 확대분석으로 천연인지 고온고압처리 된 다이아몬드인지 확인하기 어려운 vivid yellow 색상을 가진 유색 다이아 몬드의 경우 라만분석으로 $1440 \mathrm{~cm}^{-1}$ 피크를 보이는 다이 아몬드는 고온고압 처리되었을 가능성이 있음을 나타내 는 감별 근거로 타당해 보였다.

\section{4. 결 론}

$0.3 \mathrm{ct}$ 급 크기의 천연 갈색 Type I 다이아몬드 단결정을 흑 연 안정조건인 고온고압에서 처리하더라도 $5.2 \mathrm{GPa} / 5 \mathrm{~min} /$ $1600 \sim 2300^{\circ} \mathrm{C}$ 범위에서 성공적인 색향상이 가능하였으나 표면부에 한정하여 흑연층이 생기는 특징이 있었고 이 흑 연층은 고상의 핵생성과 성장 메커니즘으로 두꺼워졌다. $2150^{\circ} \mathrm{C} / 5 \mathrm{~min}$ 에서 $4.2 \sim 5.7 \mathrm{GPa}$ 공정조건도 압력이 낮아 지면서 색향상이 가능하였으나 흑연층이 두껍게 생성되 었다. 이러한 흑연층은 선택적인 재연마로 중량손실을 감 
수하면 보석으로서 활용이 가능하였다. 고온고압 처리와 재연마된 다이아몬드들을 마이크로 라만으로 측정하면 $1440 \mathrm{~cm}^{-1}$ 특성피크로부터 처리유무를 확인할 수 있는 감 별 근거가 될 수 있었다.

\section{Acknowledgment}

이 논문은 2012년도 정부(교육과학기술부)의 재원으로 한국연구재단의 기초연구사업 지원을 받아 수행된 연구 임(2012-0002601).

\section{REFERENCES}

1. G. E. Harlow, "The Nature of Diamonds, American Museum of Natural History," pp. 214-72, Cambridge University Press, New York, 1998.

2. A. V. Nikiin, M. I. Samoilovich, G. N. Bezrukov, and K. F. Vorozheikin, "The Effect of Heat and Pressure on Certain Physical Properties of Diamonds," Sov. Phys. Dokl., 13 84244 (1968).

3. T. Evans and P. Rainey, "Changes in the Defect Structure of Diamond due to the High Temperature High Pressure Treatment," Proc. Royal Soc., 344 111-30 (1975).
4. R. M. Chrenko, R. E. Tuft, and H. M. Strong, "Transformation of the State of Nitrogen in Diamond," Nature, 270 141-44 (1977).

5. Vagarali, "High Pressure/High Temperature Production of Colorless and Fancy-Colored Diamonds (in USA)," Eng. Patent, US7323156, 2008.

6. F. Li, "Color Enhancement of Natural Brown Tinted Diamonds by HPHT," pp. 123-4, M.S. Thesis, University of Seoul, 2011

7. M. Perraki, A. Proyer, E. Mposkos, R. Kaindl, and G. Hoinkes, "Raman Micro-Spectroscopy on Diamond, Graphite and Other Carbon Polymorphs from the Ultrahigh-Pressure Metamorphic Kimi Complex of the Rhodope Metamorphic Province, NE Greece," Earth Planet Sci. Lett., 241 672-85 (2006).

8. F. Li, Y. Shen, H. M. Choi, Y. C. Kim, and O. S. Song, "The Color Enhancement of Brown Tinted Diamonds with Annealing Time in HPHT," J. Kor. Gems and Jewelry, 5 [1] 1-6 (2011).

9. D. A. Porter, K. E. Easterling, M. Y. Sherif, "Phase Transformations in Metals and Alloys-Third Edition," pp. 31-41, CRC Press, New York, 2008.

10. F. Li and O. S. Song, "The Color Enhancement of Brown Tinted Diamonds with Annealing Temperatures in 5.6 GPa10min HPHT," Kor. J. Met. Mater, 50 [1] 23-7 (2012). 